\title{
The Agile Content Marketing Roadmap Based on the B2B Buyer's Journey - The Case Study of the Slovak republic
}

\author{
Lubica Gajanova ${ }^{1, *}$ \\ ${ }^{1}$ University of Zilina, Faculty of Operation and Economics of Transport and Communications, \\ Department of Economics, Zilina, Slovakia
}

\begin{abstract}
The rise of new technologies has created opportunities for the emergence of many trends today. This fact is a chance for the visibility of companies and in recent years internet marketing has become an integral part of marketing strategies of companies across all markets. Today's marketing world give new opportunities to engage and gain the attention of relevant users. But customers including B2B buyers are overwhelmed by advertising on the Internet. Emphasis on the creation of quality content therefore becomes necessary and creates another of the right ways to address customers. This paper deals with the use of content marketing strategy in the B2B market in the conditions of the Slovak Republic. As there are a large number of tools usable in the content marketing strategy, the aim of the paper is to use factor analysis to obtain an alternative description of the variability of the observed variables (B2B content marketing tools) with a potentially lower number of latent variables.
\end{abstract}

Keywords: content marketing, B2B, factor analysis, buyer's journey, Slovakia

\section{Introduction}

The awareness of B2B buyers is currently growing thanks to better connectivity and the use of modern technologies. The communication resources that the current environment offers influence them, but it also offers a choice between an inexhaustible number of messages and appeals coming from the market. [1]. B2B buyers therefore choose the information they want to receive. As a result, they become more resilient to marketing incentives [2]. The spiral of advertising chaos or advertising blindness sends a clear signal to companies about the unsustainability of this phenomenon, which forces them to make significant efforts to communicate the message [3]. The problem outlined therefore represents a space for finding effective marketing ways to help break down these barriers. In this connection, it is necessary to realize that the customer is basically not so interested in the goods or services of a particular company, they are primarily interested in themselves and their needs, which they want to satisfy through these products $[4,5]$. This finding is not new, but it took some time for such marketing forms to develop that were truly and

"Corresponding author: lubica.gajanova@uniza.sk 
effectively able to absorb this fact into its essence. Therefore, they do not primarily prioritize the product itself, but first solve the customer's problems, needs and interests, offer him a solution and sensitively incorporate advertising messages into the communication $[6,7]$. The notion of repeatedly targeting the customer with the idea that someone will be eventually attract by the product to buy it is no longer enough. The technique, which is defined as content marketing, tries to solve this problem [8,9]. Content marketing plays an important role for business-to-business (B2B) companies due to the higher (than for business-to-customers (B2C) companies) dependence on customers [10, 11]. Nearly all of the most successful B2B content marketers $(90 \%)$ prioritize the audience's informational needs over their sales/promotional message, compared with $56 \%$ of the least successful [12].

Despite the assumptions, content marketing is currently used by more than $90 \%$ of companies worldwide in the B2B sector [13]. In fact, up to $93 \%$ of B2B companies say that content marketing can attract more potential customers than traditional marketing strategies [14]. The data confirm that in the B2B sector, more than half of all buyers will encounter several digital communication tools during the purchasing process. And more than $80 \%$ of buyers view various publications about the company, its successes and references [15]. Almost $75 \%$ of buyers say that the content they find significantly affects their purchase decision. And $62 \%$ say they can complete their selection criteria based only on digital content when making a purchase [16]. The research carried out by B-inside in 2013 focused directly on the use of content marketing in the B2B segment in the Czech Republic. The results were very favourable. $95 \%$ of $\mathrm{B} 2 \mathrm{~B}$ marketers used at least one of the content marketing tools. Most of them were articles in magazines, newspapers. Furthermore, verbal references of clients, articles on the Internet, seminars, etc. [17]. According to further research by this company in 2017, companies are deviated away from using content. Companies started to pay less attention to content marketing, PR, e-mail marketing, etc. On the contrary, they started to pay more attention to sales support, sponsorship, etc. [18]. However, the survey in 2019 again showed an increase in interest in content marketing in the B2B segment. While in 2017 only 16\% of B2B in the Czech Republic used it, in 2019 it was already 36\%. However, most (77\%) B2B companies engage in content marketing unsystematically, but at least create and distribute some content. The systematic approach existed only in a minority of cases. That is the situation which has not changed much compared to 2016. Even then, only about a quarter of B2B companies regularly created and communicated interesting content [19].

How it is in Slovakia is not known. Likewise, academic research on this topic is in its infancy. We encounter a situation in which technology and society are evolving faster than the ability of companies to adapt to new conditions. This phenomenon is collectively referred to digital Darwinism [20]. The vast majority of the approach to content marketing discussed so far has not been differentiated with regard to a specific area of targeting, and therefore we do not know what quality content means specifically for the customer in the B2B segment in the Slovak republic. That represents the research gap for this paper, which therefore focuses on communication with corporate clients, which has its own specifics playing an important role in marketing communication, decision-making and purchasing process. There is a fundamental difference between an average content marketing strategy and an excellent content marketing strategy. This is the ability of the marketer to reveal what kind of content is appropriate in each given situation. According to Content Marketing Institute's 2020 report, $69 \%$ of successful B2B marketers have a documented content marketing strategy [16]. 


\section{Methodology}

As there are a large number of tools and techniques that can be used in content marketing, the aim of the paper is to use factor analysis to obtain an alternative description of the variability of observed variables with a potentially lower number of hidden compact latent variables (factors). Factor analysis assumes that the factor construction of the model may be simpler than the data on which it is based [21]. This construction then represents an aggregated abstraction of a large number of observed phenomena based on the presence of their common characteristics, which allows to significantly simplify and summarize large data matrices into smaller ones, without significant loss of information [22]. The information obtained in this way can lead to the creation of a content marketing roadmap of the B2B buyer's journey in conditions of the Slovak republic.

Factor analysis simplifies the description of the original configuration to the smallest possible number of dimensions. This simplification is based on the magnitude of the linear interdependence between the input variables - if the variables are linearly dependent on other variables, these variables can be described through common linearly independent hidden variables. By preserving only a subset of linearly independent hidden variables, other variables can be explicitly described by expressing their relationship to this subset $[23,24]$. The assumption is that the size of the set of latent variables will be smaller than the original set of data, i.e. the configuration of the data matrix $Y$ of size $K \times I$ can be reduced to $r$ dimension $(r \leq I)$. These $r$-dimensions then form a factor space into which the original $I$ vectors can be projected [24].

As input variables for factor analysis were selected content marketing tools usable in the B2B market $[9,10,11,25,26]$, which are shown in Figure 1.

\begin{tabular}{|l|l|l|}
\hline Newsletter / Email Marketing & Social Media Content & Reviews and Testimonials \\
\hline Blogs & Podcasts & LinkedIn Lead Generation \\
\hline Articles & Live In-Person Events & Sales Conversation \\
\hline E-books & Webinars & Demos \\
\hline White Papers & Social Media Engagement & Free Assessment \\
\hline Tip Sheets & Case Studies & Quotes/Proposals \\
\hline Checklists & Videos & Free Consultations \\
\hline Infographics/Data Viz & Live Streaming & Free Trial \\
\hline
\end{tabular}

Fig. 1. Content marketing tools

Source: Own processing.

Respondents assigned data to these content marketing techniques within the research according to a liqueur scale, which expressed the degree of influence of respondents in the purchasing process within the B2B market. The respondents were customers who had been part of the $\mathrm{B} 2 \mathrm{~B}$ purchasing team at least once during the past year.

Factor analysis is based on correlations and these are stabilized only on relatively large samples. The literature in this case states that the sample of 500 respondents is very good and some authors state that the number of respondents (cases) must be at least 5 times more than the variables for factor analysis [27]. The size of the examined sample was 500 respondents, which fulfilled both cases of conditions for determining the sufficient sample size. 


\section{Results}

The initial conditions of factor analysis include: a) high correlations of a large number of variables and b) low partial correlations. Whether the correlation and partial correlation matrices satisfy the assumptions is therefore tested by various coefficients and indices, usually KMO and Bartlett's sphericity test [21, 22, 23], see Table 1.

Table 1. KMO and Bartlett's Test

\begin{tabular}{|l|l|r|}
\hline Kaiser-Meyer-Olkin Measure of Sampling Adequacy. & & 0,927 \\
\hline Bartlett's Test of Sphericity & Approx. Chi-Square & 11064,325 \\
\hline & df & 276 \\
\hline & Sig. & 0,000 \\
\hline
\end{tabular}

Source: Own processing according SPSS.

The value of the Kaiser-Meyer-Olkin measure (KMO), i.e. the measure of the adequacy of the selection at the level of 0.951 and the significance of Bartlett's Test of Sphericity at the level of 0,000 show that the mentioned initial assumptions of factor analysis are correct, so the condition of the sample adequacy is met [22].

Table 2 shows the output of the Principal Component Analysis procedure. The input variables contain an evaluation of 24 questions, which were obtained in the survey concerning the degree of influence of respondents in the purchasing process within the $\mathrm{B} 2 \mathrm{~B}$ market.

Table 2. Total Variance Explained

\begin{tabular}{|l|r|r|r|r|r|r|r|r|r|}
\hline Comp. & \multicolumn{3}{|c|}{ Initial Eigenvalues } & \multicolumn{3}{|c|}{$\begin{array}{c}\text { Extraction Sums of Squared } \\
\text { Loadings }\end{array}$} & \multicolumn{3}{|c|}{$\begin{array}{c}\text { Rotation Sums of Squared } \\
\text { Loadings }\end{array}$} \\
\hline & Total & $\begin{array}{c}\text { \% of } \\
\text { Variance }\end{array}$ & $\begin{array}{r}\text { Cumulative } \\
\%\end{array}$ & Total & $\begin{array}{c}\text { \% of } \\
\text { Variance }\end{array}$ & $\begin{array}{r}\text { Cumulative } \\
\%\end{array}$ & Total & $\begin{array}{c}\% \text { of } \\
\text { Variance }\end{array}$ & $\begin{array}{c}\text { Cumulative } \\
\%\end{array}$ \\
\hline 1 & 11,476 & 47,815 & 47,815 & 11,476 & 47,815 & 47,815 & 5,810 & 24,209 & 24,209 \\
\hline 2 & 3,247 & 13,530 & 61,346 & 3,247 & 13,530 & 61,346 & 4,149 & 17,288 & 41,497 \\
\hline 3 & 1,613 & 6,719 & 68,065 & 1,613 & 6,719 & 68,065 & 4,047 & 16,861 & 58,359 \\
\hline 4 & 1,466 & 6,110 & 74,175 & 1,466 & 6,110 & 74,175 & 3,796 & 15,816 & 74,175 \\
\hline 5 & 0,881 & 3,670 & 77,846 & & & & & & \\
\hline 6 & 0,728 & 3,034 & 80,880 & & & & & & \\
\hline 7 & 0,564 & 2,351 & 83,231 & & & & & & \\
\hline 8 & 0,431 & 1,796 & 85,027 & & & & & & \\
\hline 9 & 0,385 & 1,604 & 86,631 & & & & & & \\
\hline 10 & 0,349 & 1,454 & 88,085 & & & & & & \\
\hline 11 & 0,331 & 1,379 & 89,464 & & & & & & \\
\hline 12 & 0,317 & 1,322 & 90,786 & & & & & & \\
\hline 13 & 0,281 & 1,171 & 91,958 & & & & & & \\
\hline 14 & 0,277 & 1,155 & 93,113 & & & & & & \\
\hline 15 & 0,245 & 1,022 & 94,134 & & & & & & \\
\hline 16 & 0,223 & 0,931 & 95,065 & & & & & & \\
\hline 17 & 0,196 & 0,818 & 95,882 & & & & & & \\
\hline
\end{tabular}




\begin{tabular}{|l|r|r|r|l|l|l|l|l|l|}
18 & 0,187 & 0,779 & 96,661 & & & & & & \\
\hline 19 & 0,173 & 0,719 & 97,380 & & & & & & \\
\hline 20 & 0,148 & 0,615 & 97,995 & & & & & & \\
\hline 21 & 0,137 & 0,573 & 98,568 & & & & & & \\
\hline 22 & 0,129 & 0,539 & 99,107 & & & & & & \\
\hline 23 & 0,114 & 0,474 & 99,581 & & & & & & \\
\hline 24 & 0,101 & 0,419 & 100,000 & & & & & & \\
\hline
\end{tabular}

Source: Own processing according SPSS.

The procedure with the extraction Principal Component Analysis revealed four significant factors in the input data, which explain $74,175 \%$ of the variability of the observed variables.

Table 3 shows the Rotation matrix by Varimax with Kaiser Normalization and contains the structure of the individual components and their loads expressing the degree of correlation of the variable with the given component [21]. In this case, all component loads came out high enough for unambiguous interpretation. 
Table 3. Rotated Component Matrix

\begin{tabular}{|c|c|c|c|c|}
\hline & \multicolumn{4}{|c|}{ Component } \\
\hline Attributes (Variables) & 1 & 2 & 3 & 4 \\
\hline Newsletter / Email Marketing & 0,765 & 0,146 & 0,089 & 0,178 \\
\hline $\mathrm{B} \log s$ & 0,754 & 0,036 & 0,166 & 0,253 \\
\hline Articles & 0,677 & 0,036 & 0,192 & 0,224 \\
\hline E-books & 0,845 & 0,141 & 0,182 & 0,110 \\
\hline White Papers & 0,834 & 0,209 & 0,129 & 0,100 \\
\hline Tip Sheets & 0,852 & 0,180 & 0,089 & 0,133 \\
\hline Checklists & 0,821 & 0,159 & 0,130 & 0,168 \\
\hline Infographics / Charts / Data Viz & 0,879 & 0,168 & 0,158 & 0,094 \\
\hline Social Media Content & 0,211 & 0,216 & 0,304 & 0,755 \\
\hline Podcasts & 0,215 & 0,271 & 0,230 & 0,787 \\
\hline Live In-Person Events & 0,273 & 0,231 & 0,236 & 0,771 \\
\hline Webinars & 0,215 & 0,215 & 0,288 & 0,787 \\
\hline Social Media Engagement & 0,178 & 0,265 & 0,159 & 0,723 \\
\hline Case Studies & 0,203 & 0,783 & 0,250 & 0,303 \\
\hline Videos & 0,144 & 0,773 & 0,289 & 0,181 \\
\hline Live Streaming & 0,168 & 0,762 & 0,317 & 0,243 \\
\hline Reviews and Testimonials & 0,158 & 0,822 & 0,204 & 0,252 \\
\hline LinkedIn Lead Generation & 0,169 & 0,826 & 0,161 & 0,223 \\
\hline Sales Conversation & 0,166 & 0,170 & 0,837 & 0,249 \\
\hline Demos & 0,165 & 0,236 & 0,818 & 0,217 \\
\hline Free Assessment & 0,254 & 0,440 & 0,654 & 0,167 \\
\hline Quotes/Proposals & 0,131 & 0,194 & 0,774 & 0,313 \\
\hline Free Consultations & 0,215 & 0,222 & 0,723 & 0,334 \\
\hline Free Trial & 0,209 & 0,412 & 0,576 & 0,070 \\
\hline
\end{tabular}

Source: Own processing according SPSS.

The first component strongly correlates with the eight variables (Newsletter / Email Marketing, Blogs, Articles, E-books, White Papers, Tip Sheets, Checklists, Infographics / Charts / Data Viz) and together form one dimension of content marketing tools and techniques. Similarly, the second component brings together five other variables (Case Studies, Videos, Live Streaming, Reviews and Testimonials, LinkedIn Lead Generation). The third component consists of an exclusive representation of six variables (Sales Conversation, Demos, Free Assessment, Quotes / Proposals, Free Consultations, Free Trial). The last fourth component contains five variables (Social Media Content, Podcasts, Live In-Person Events, Webinars, Social Media Engagement).

\section{Discussion}

The results of the factor analysis of content marketing tools and techniques showed that the respondents divided the given tools into four dimensions within the examination of their degree of influence of the respondents during the purchasing process within the $\mathrm{B} 2 \mathrm{~B}$ market. By examining their structure, we can assign them properties derived from 
contributing attributes that have clearly demonstrated the creation of dimensions in accordance with the each stages of the B2B buyer's journey based on the See-Think-DoCare framework for the digital age [28]. It is a method that enables clear content planning and generally helps in creating a marketing strategy for the company's products and services, so it is suitable for content marketing [10]. The model works on the assumption that one customer is in four different phases during the purchasing process [29].

For a content marketing strategy, it is essential to reveal what type of content is appropriate in each given situation. Figure 2 shows a closely related link between content marketing tools and techniques with a specific phase of the B2B buyer's journey.

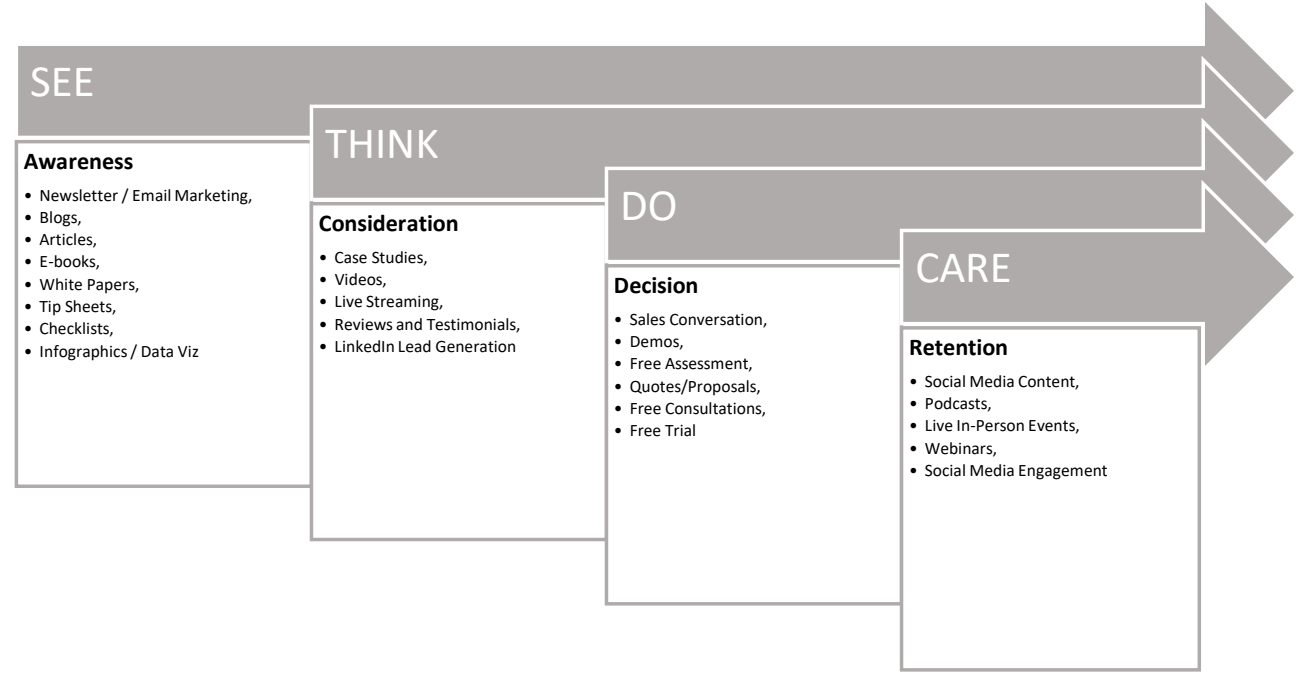

Fig. 2. The agile content marketing roadmap based on the B2B buyer's journey

Source: Own processing.

The B2B buyer's journey is one of the most important elements of a marketing strategy. For a content marketing strategy to be successful, the seller must be able to target it to the right audience and address it with the right message at the right time [10]. In addition, B2B marketers will understand what their buyers are doing and help them move from one stage of decision making to another.

\section{Conclusion}

The paper dealt with the issue of content marketing and its connection to the creation of a content marketing roadmap on the B2B buyer's journey in the conditions of the Slovak republic. The main idea of the work was to show how the tools of content marketing can be optimally used in the B2B market. Along with a full understanding of buyer's journey, it should be possible to build a targeted marketing strategy. The construction of factor analysis abstracted a large number of content marketing tools and techniques based on the statistical existence of their common features and characteristics, and thus significantly reduced data matrices to four dimensions in accordance with the each stages of the B2B buyer's journey based on the See-Think-Do- Care framework. The information thus obtained led to the creation of a content marketing roadmap of the B2B buyer's journey in conditions of the Slovak republic. 


\section{Acknowledgement}

This paper is an output of scientific project VEGA no. 1/0718/18: The impact of psychographic aspects of pricing on the marketing strategy of companies across products and markets.

\section{References}

1. A. Domańska, Cooperation between knowledge-based institutions and business: empirical studies and network theories. Forum Scientiae Oeconomia, 6(4), 81-94 (2018)

2. J. Majerova, Analysis of Slovak Consumer's Perception of the Green Marketing Activities. Proceedings of the 4th World Conference on Business, Economics and Management (WCBEM), pp. 553-560 (2015)

3. A. Aribarg, E. M. Schwartz, Native Advertising in Online News: Trade-Offs Among Clicks, Brand Recognition, and Website Trustworthiness. Journal of Marketing Research, 57(1), 20-34 (2020)

4. M. Nadanyiova, The Possibility of Introducing the CRM System in Railway Company Cargo Slovakia. Proceedings of the 17th International Conference on Transport Means, pp 87-92 (2013)

5. A. Krizanova, J. Majerova, K. Zvarikova, Green Marketing as a Tool of Achieving Competitive Advantage in Automotive Transport. Proceedings of the 17th International Conference on Transport Means, pp. 45-48 (2013)

6. J. Ǩezníček, T. Procházka, Obsahový marketing: nakrmte Internet svým obsahem. $1^{\text {st }}$ ed. Brno: Computer Press (2014)

7. M. Valaskova, A. Krizanova, The passenger satisfaction survey in the regional integrated public transport system. Promet-Traffic \& Transportation, 20(6), 401404 (2008)

8. S. Yaghtin, H. Safarzadeh, M. Karimi Zand, Planning a goal-oriented B2B content marketing strategy. Marketing Intelligence \& Planning, Early Access (2020)

9. J. Jarvinen, H. Taiminen, Harnessing marketing automation for B2B content marketing. Industrial Marketing Management, 54, 164-175 (2016)

10. E. Bakhtieva, The role of customer journey in B2B content marketing. Proceedings of the 12th Annual International Bata Conference for Ph.D. Students and Young Researchers (DOKBAT), pp. 31-42 (2016)

11. J. Horvath, M. Olearova, Importance and effectiveness of content marketing in conditions of e-commerce B2B model. Proceedings of the International Scientific Conference on Marketing Identity: Online Rules, pp. 93-103 (2017)

12. Content Marketing Institute. B2B Content Marketing 2019 Benchmarks, Budgets, and Trends [online], Available at: https://contentmarketinginstitute.com/wpcontent/uploads/2018/10/2019_B2B_Research_Final.pdf (2019)

13. Content Marketing Institute. B2B Content Marketing 2018 Benchmarks, Budgets, and Trends [online], Available at: https://contentmarketinginstitute.com/wpcontent/uploads/2017/09/2018-b2b-research-final.pdf_(2018)

14. Forbes._Obsahový marketing a hodnotný obsah. Tu sú 3 stratégie, ktoré v roku 2019 fungujú_[online], Available at: https://www.forbes.sk/obsahovy-marketinghodnotny-obsah-tu-su-3-strategie-ktore-v-roku-2019-funguju/_(2019) 
15. P. Andersen, R. Archacki, N. de Bellefonds, D. Ratajczak, How Digital Leaders Are Transforming B2B Marketing [online], Available at: https://www.bcg.com/enus/publications/2017/marketing-sales-how-digital-leaders-transforming-b2b (2017)

16. Content Marketing Institute. B2B Content Marketing 2020 Benchmarks, Budgets, and Trends [online], Available at: https://contentmarketinginstitute.com/wpcontent/uploads/2019/10/2020_B2B_Research_Final.pdf (2020)

17. B-inside. Ministudie: Content marketing $v B 2 B v \check{C} R$ a USA, 2013 [online], Available at: http://www.b2bmonitor.cz/wp-content/uploads/2013/11/B2Bmonitor-VI-Content-marketing-bez-sektor\%C5\%AF.pdf (2013)

18. B-inside. $B 2 B$ marketing $v \check{C} R \quad v$ roce 2017 [online], Available at: http://www.b2bmonitor.cz/wp-content/uploads/2017/10/B2B-marketing-v\%C4\%8CR-v-roce-2017-ve\%C5\%99ejn\%C3\%A1-studie-FINAL.pdf (2017)

19. B-inside. Content marketing v B2B v roce 2019 [online], Available at: http://www.b2bmonitor.cz/wp-content/uploads/2019/03/B2B-monitor-Contentmarketing-v-B2B-v-roce-2019.pdf_(2019)

20. B. Solis, WTF?: What's the Future of Business?: Changing the Way Businesses Create Experiences. $1^{\text {st }}$ ed. Wiley (2013)

21. P. Durana, J. Kliestikova, M. Kovacova, The Quality of Brand Products: Expected Attributes vs. Perceived Reality. Economics and Culture, 16(1), 98-107 (2019)

22. J. Kliestikova, M. Kovacova, P. Durana, Quo vadis brand loyalty? Comparative study of perceived brand value sources. Polish Journal of Management Studies, 19(1), 190-203 (2019)

23. J. Kliestikova, P. Durana, M. Kovacova, Naked consumer's mind under branded dress: Case study of Slovak Republic. Central European Business Review, 8(1), 15-32 (2019)

24. D. J. Tigert, J. N. Sheth, Factor Analysis in Marketing. Marketing Classics Press (2011).

25. W. L. Wang, E. C. Malthouse, B. Calder, B2B content marketing for professional services: In-person versus digital contacts. Industrial Marketing Management, 81, 16-168 (2019)

26. F. Stroch, M. Stoklasa, Methods for creating personalized marketing content in B2B online communication. Proceedings of the International Scientific Conference on Marketing Identity: Online Rules, pp. 434-439 (2017)

27. A. B. Costello, J. W. Osborne, Best Practices in Exploratory Factor Analysis: Four Recommendations for Getting the Most From Your Analysis. Practical Assessment, Research \& Evaluation, 10, 7 (2005)

28. A. Kaushik, See, Think, Do, Care Winning Combo: Content +Marketing +Measurement! [online], Available at: https://www.kaushik.net/avinash/see-thinkdo-care-win-content-marketing-measurement/ (2015)

29. D. Rowles, Digital Branding: A Complete Step-by-Step Guide to Strategy, Tactics and Measurement. Kogan Page (2014) 